Organometallics. 2018 June 11; 37(11): 1641-1644. doi:10.1021/acs.organomet.8b00168.

\title{
Synthesis of High-Oxidation-State $\mathrm{Mo}=\mathrm{CHX}$ Complexes, Where $\mathrm{X}=\mathrm{CI}, \mathrm{CF}_{3}$, Phosphonium, $\mathrm{CN}$
}

\author{
Sudarsan VenkatRamami ${ }^{\ddagger}$, Richard R. Schrock $^{\ddagger},{ }^{,}$, Amir Hoveyda $^{\dagger}$, Peter Müller ${ }^{\ddagger}$, and \\ Charlene Tsay $\ddagger$ \\ FDepartment of Chemistry 6-331, Massachusetts Institute of Technology, Cambridge, \\ Massachusetts 02139 \\ †Department of Chemistry, Merkert Chemistry Center, Boston College, Chestnut Hill, \\ Massachusetts 02467
}

\section{Abstract}

Reactions between $Z-\mathrm{XCH}=\mathrm{CHX}$ where $\mathrm{X}=\mathrm{Cl}, \mathrm{CF}_{3}$, or $\mathrm{CN}$ and $\mathrm{Mo}(\mathrm{N}-\mathrm{t}-\mathrm{Bu})(\mathrm{CH}-t-\mathrm{Bu})$ $(\mathrm{OHIPT}) \mathrm{Cl}\left(\mathrm{PPh}_{2} \mathrm{Me}\right)\left(\mathrm{OHIPT}=\mathrm{O}-2,6-\left(2,4,6-i-\mathrm{Pr}_{3} \mathrm{C}_{6} \mathrm{H}_{2}\right)_{2} \mathrm{C}_{6} \mathrm{H}_{3}\right)$ produce $\mathrm{Mo}(\mathrm{N}-t-\mathrm{Bu})(\mathrm{CHX})$ $(\mathrm{OHIPT}) \mathrm{Cl}\left(\mathrm{PPh}_{2} \mathrm{Me}\right)$ complexes. Addition of 2,2'-bipyridyl (Bipy) yields $\mathrm{Mo}(\mathrm{N}-\mathrm{t}-\mathrm{Bu})(\mathrm{CHX})$ (OHIPT)Cl(Bipy) complexes, which could be isolated and structurally characterized. The reaction between $\mathrm{Mo}(\mathrm{N}-t-\mathrm{Bu})(\mathrm{CH}-t-\mathrm{Bu})(\mathrm{OHMT}) \mathrm{Cl}\left(\mathrm{PPh}_{2} \mathrm{Me}\right)\left(\mathrm{OHMT}=\mathrm{O}-2,6-\left(2,4,6-\mathrm{Me}_{3} \mathrm{C}_{6} \mathrm{H}_{2}\right)_{2} \mathrm{C}_{6} \mathrm{H}_{3}\right)$ and $Z-\mathrm{ClCH}=\mathrm{CHCl}$ in the presence of Bipy produces a mixture that contains both $\mathrm{Mo}(\mathrm{N}-t-\mathrm{Bu})$ $(\mathrm{CHCl})(\mathrm{OHMT}) \mathrm{Cl}\left(\mathrm{PPh}_{2} \mathrm{Me}\right)$ and $\mathrm{Mo}(\mathrm{N}-t-\mathrm{Bu})(\mathrm{CHCl})(\mathrm{OHMT}) \mathrm{Cl}(\mathrm{Bipy})$, but the relatively insoluble product that crystallizes from toluene- $d_{8}$ is the phosphoniomethylidene complex, $\left[\mathrm{Mo}(\mathrm{N}-t-\mathrm{Bu})\left(\mathrm{CHPPh}_{2} \mathrm{Me}\right)(\mathrm{OHMT})(\mathrm{Cl})(\mathrm{Bipy})\right] \mathrm{Cl}$. The $\mathrm{Mo}(\mathrm{N}-t-\mathrm{Bu})(\mathrm{CHX})(\mathrm{OHIPT}) \mathrm{Cl}\left(\mathrm{PPh}_{2} \mathrm{Me}\right)$ complexes $\left(\mathrm{X}=\mathrm{Cl}\right.$ or $\left.\mathrm{CF}_{3}\right)$ were confirmed to initiate the stereoselective cross-metathesis between $Z$-5-decene and $Z$-XCH=CHX.

\begin{abstract}
Monoaryloxide monochloride molybdenum-based metathesis initiators of the type Mo(NR) $\left(\mathrm{CHR}^{\prime}\right)(\mathrm{OAr}) \mathrm{Cl}(\mathrm{L})$ (where $\mathrm{OAr}$ is a sterically demanding 2,6-terphenoxide ${ }^{1}$ and $\mathrm{L}$ a $2 \mathrm{e}$ donor ligand) have been found to promote stereoselective $(E$ or $Z$ ) metathesis reactions between "ordinary" olefins and $\mathrm{ClCH}=\mathrm{CHCl}, \mathrm{BrCH}=\mathrm{CHF}$, or $\left(\mathrm{CF}_{3}\right) \mathrm{CH}=\mathrm{CH}\left(\mathrm{CF}_{3}\right){ }^{2}$ Vinyl halides are desirable cross-partners in cross-metathesis reactions because alkenyl halide ( $\mathrm{X}=$ $\mathrm{Cl}$ or $\mathrm{Br}$ ) products subsequently can be used in other catalytic reactions. ${ }^{2 \mathrm{e}} \mathrm{Ruthenium-}$ catalyzed cross-metathesis reactions that use vinyl chlorides $\left(\mathrm{CH}_{2}=\mathrm{CHCl}, \mathrm{ClCH}=\mathrm{CHCl}(E\right.$ or $Z$ ), or $E-\mathrm{MeCH}=\mathrm{CHCl}$ ) or fluorides have been the subject of several investigations periodically since $2000 .{ }^{3}$ Although alkenyl halide products have been observed, the reactions are not stereoselective and turnovers are limited, in part due to formation of ruthenium carbide complexes. ${ }^{4}$ The preparation and isolation of $\mathrm{Mo}=\mathrm{CHX}$ complexes are keys to understanding the stabilities and reactivities of $\mathrm{Mo}=\mathrm{CHX}$ complexes versus
\end{abstract}

\footnotetext{
*Corresponding Author: rrs@mit.edu.

Supporting Information

The following Supporting Information is available free of charge on the ACS Publications website: (i) Full experimental details including NMR data and spectra for new compounds; (ii) X-ray crystallographic files for four complexes.

The authors declare no competing financial interests.
} 
$\mathrm{Mo}=\mathrm{CHR}$ complexes in cross-metathesis reactions, where $\mathrm{R}$ is a carbon-based group, or $\mathrm{H}$. To our knowledge no $\mathrm{Mo}=\mathrm{CHX}$ intermediate in a cross-metathesis reaction that involves $\mathrm{XCH}=\mathrm{CHX}$ (e.g., $\mathrm{X}=\mathrm{Cl}$ or $\mathrm{CF}_{3}$ ) has been observed. We have now found a way to prepare $\mathrm{Mo}=\mathrm{CHCl}, \mathrm{Mo}=\mathrm{CHCF}_{3}$, and $\mathrm{Mo}=\mathrm{CHCN}$ complexes, and have structurally characterized 2,2'-bipyridine adducts thereof.

Recently we found that the most successful $\mathrm{Mo}(\mathrm{N}-t-\mathrm{Bu})(\mathrm{CH}-t-\mathrm{Bu})(\mathrm{OAr}) \mathrm{Cl}\left(\mathrm{PPh}_{2} \mathrm{Me}\right)$ initiators in the test reaction shown in equation 1 are those in which OAr is OHMT (in 1a) or OHIPT (in 1b). ${ }^{5}$ The reason is that the large OAr ligand encourages dissociation of $\mathrm{PPh}_{2} \mathrm{Me}$, which is required to access to the catalytically active $14 \mathrm{e} \mathrm{Mo}(\mathrm{N}-t-\mathrm{Bu})(\mathrm{CH}-t-\mathrm{Bu})(\mathrm{OAr}) \mathrm{Cl}$ core. A low degree of dissociation of phosphine is therefore likely to be the reason why complexes in which $\mathrm{OAr}=\mathrm{O}-2,3,5,6$-tetraphenylphenoxide are relatively inactive. We also found that although $\mathrm{PPh}_{2} \mathrm{Me}$ is fully dissociated when $\mathrm{OAr}=$ hexa- $t$-butylterphenoxide (OHTBT),${ }^{6}$ the $14 \mathrm{e} \mathrm{Mo}(\mathrm{N}-t-\mathrm{Bu})(\mathrm{CH}-\mathrm{t}-\mathrm{Bu})(\mathrm{OHTBT}) \mathrm{Cl}$ core is simply too crowded to react readily with either cyclooctene or $Z-\mathrm{ClCH}=\mathrm{CHCl}$. Therefore, we felt that reactions of $\mathbf{1 a}$ and $1 \mathbf{b}$ with $Z-\mathrm{ClCH}=\mathrm{CHCl}$ could provide the opportunity to observe and isolate $\mathrm{Mo}=\mathrm{CHCl}$ complexes.
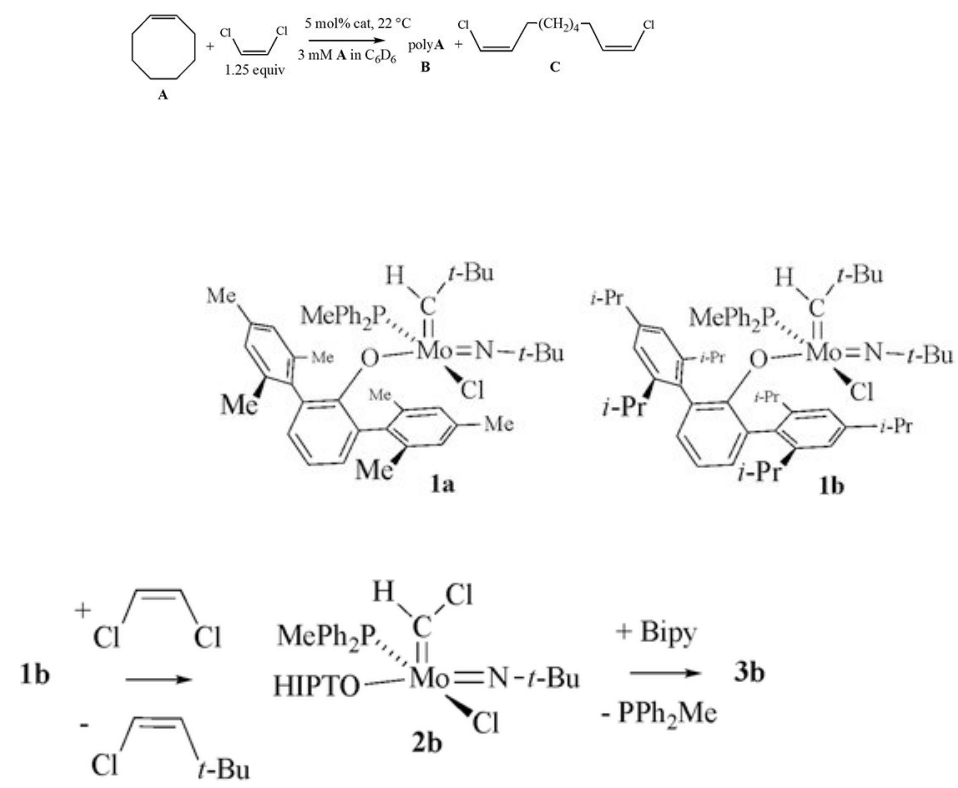

Compound $\mathbf{1 b}$ reacts in seconds with several equivalents of $Z$-ClCH=CHCl ( $Z$-DCE) in $\mathrm{C}_{6} \mathrm{D}_{6}$ or toluene- $d_{8}$ at $22{ }^{\circ} \mathrm{C}$ to give $Z-\mathrm{ClCH}=\mathrm{CH}-t-\mathrm{Bu}$ and what we propose is $\mathrm{Mo}(\mathrm{N}-t-\mathrm{Bu})$ $(\mathrm{CHCl})(\mathrm{OHIPT}) \mathrm{Cl}\left(\mathrm{PPh}_{2} \mathrm{Me}\right)(\mathbf{2 b})$. Its alkylidene proton resonance is a doublet at $9.56 \mathrm{ppm}$ in $\mathrm{C}_{6} \mathrm{D}_{6}$ with $J_{\mathrm{HP}}=5.3 \mathrm{~Hz}$ and $J_{\mathrm{CH}}=156 \mathrm{~Hz}$. A ${ }^{1} \mathrm{H}_{-}{ }^{13} \mathrm{C}$ HSQC NMR experiment locates the alkylidene $\mathrm{C}_{\mathbf{a}}$ resonance at $267.7 \mathrm{ppm}$. The high solubility of $\mathbf{2 b}$ prevented its crystallization, so Bipy was added to give $\mathrm{Mo}(\mathrm{N}-t-\mathrm{Bu})(\mathrm{CHCl})(\mathrm{OHIPT}) \mathrm{Cl}(\mathrm{Bipy})(\mathbf{3 b})$, whose alkylidene resonance is observed at $10.19 \mathrm{ppm}$ in toluene- $d_{8}\left(J_{\mathrm{CH}}=155 \mathrm{~Hz}\right)$. Removal of 
solvent in vacuo and trituration of the residue allowed pure $\mathbf{3 b}$ to be isolated and recrystallized.

An X-ray structural study (Figure 1) showed $\mathbf{3 b}$ to contain a syn alkylidene $(\mathrm{Cl}$ points toward the imido ligand) with the Bipy ligand coordinated trans to the alkylidene and chloride ligands. The alkylidene proton was located in the difference Fourier map (Mo1-C1$\left.\mathrm{H} 1=120(2)^{\circ}\right)$. The Mo1-C1-Cl angle $\left(128.92(18)^{\circ}\right)$ and the $\mathrm{Mo}=\mathrm{C} 1$ distance $(1.944 \AA)$ are not unusual for high oxidation state Mo syn alkylidene complexes (see SI). ${ }^{7}$ The value for $J_{\mathrm{CH}}(154 \mathrm{~Hz})$ in $\mathbf{2 b}$ is high compared to a $J_{\mathrm{CH}}$ expected for a syn Mo=CHR analog when $\mathrm{R}$ is a carbon-based group $(115-130 \mathrm{~Hz})$, but $J_{\mathrm{CH}}$ values in vinyl halides are inherently high. ${ }^{8}$ The structure of $\mathrm{Mo}(\mathrm{N}-t-\mathrm{Bu})(\mathrm{CHCl})(\mathrm{OHIPT}) \mathrm{Cl}\left(\mathrm{PPh}_{2} \mathrm{Me}\right)(\mathbf{2} \mathbf{b}$, eq 2$)$ is proposed to be analogous to that of $\mathrm{Mo}(\mathrm{N}-t-\mathrm{Bu})(\mathrm{CH}-t-\mathrm{Bu})(\mathrm{OHMT}) \mathrm{Cl}\left(\mathrm{PPh}_{2} \mathrm{Me}\right),{ }^{5}$ a square pyramid $(\tau=$ $0.24)^{9}$ with the alkylidene in the apical position and the $\mathrm{N}-t$-Bu and OHMT ligands trans to one another.

The reaction between $1 \mathrm{a}$ and $Z-\mathrm{ClCH}=\mathrm{CHCl}$ in toluene- $d_{8}$ at $22{ }^{\circ} \mathrm{C}$ is sluggish compared to the rate of the reaction between $\mathbf{1 b}$ and $Z-\mathrm{ClCH}=\mathrm{CHCl}$ because $\mathrm{PPh}_{2} \mathrm{Me}$ is not dissociated in the OHMT complex to as great an extent in $\mathbf{1 a}$ as it is in $\mathbf{1 b}$. Upon heating the reaction mixture to $50{ }^{\circ} \mathrm{C}$ for $2 \mathrm{~h}$ a doublet alkylidene resonance that we ascribe to $\mathrm{Mo}(\mathrm{N}-t-\mathrm{Bu})$ $(\mathrm{CHCl})(\mathrm{OHMT}) \mathrm{Cl}\left(\mathrm{PPh}_{2} \mathrm{Me}\right)(\mathbf{2 a})$ appears at $11.08 \mathrm{ppm}$ along with $Z-\mathrm{ClCH}=\mathrm{CH}-t-\mathrm{Bu}$ olefinic proton resonances. Addition of Bipy to $\mathbf{2 a}$ and heating the sample to $50{ }^{\circ} \mathrm{C}$ led to formation of what we propose is $\mathrm{Mo}(\mathrm{N}-t-\mathrm{Bu})(\mathrm{CHCl})(\mathrm{OHMT}) \mathrm{Cl}(\mathrm{Bipy})(3 \mathbf{a})$, which has an alkylidene resonance at $10.5 \mathrm{ppm}$. Continued heating leads to deposition of crystals on the walls of the NMR tube as the intensity of the alkylidene resonance for $\mathbf{3 a}$ declines. The isolated crystals $(\mathbf{4 a})$ were found to exhibit a doublet alkylidene proton resonance at 12.81 ppm with $J_{\mathrm{HP}}=4.1 \mathrm{~Hz}\left(\right.$ in $\mathrm{CD}_{2} \mathrm{Cl}_{2}$ ).

An X-ray structural study (Figure 2) of $\mathbf{4 a}$ showed it to be the "phosphoniomethylidene" derivative, $\left[\mathrm{Mo}(\mathrm{N}-\mathrm{t}-\mathrm{Bu})\left(\mathrm{CHPPh}_{2} \mathrm{Me}\right)(\mathrm{OHMT}) \mathrm{Cl}(\mathrm{Bipy})\right] \mathrm{Cl}$. Phosphoniomethylidene complexes were first prepared employing anions of phosphorus ylides. ${ }^{10}$ Sundermeyer has also published several examples (e.g., for $\mathrm{Nb}, \mathrm{Ta}, \mathrm{W}$, and $\mathrm{Re}$ ), ${ }^{11}$ but phosphoniomethylidene complexes perhaps are best known for Ru complexes of the type that are active for olefin metathesis. ${ }^{12}$ They usually are formed in a reaction between an intermediate, and sometimes observable, $\mathrm{Ru}=\mathrm{CHCl}$ complex, and a phosphine originally present on the metal.

Metathesis reactions have been reported that use $Z-\left(\mathrm{CF}_{3}\right) \mathrm{CH}=\mathrm{CH}\left(\mathrm{CF}_{3}\right)(Z-\mathrm{HFB})$ as a crossmetathesis partner and $\mathrm{Mo}(\mathrm{N}-t-\mathrm{Bu})(\mathrm{CH}-t-\mathrm{Bu})(\mathrm{OHIPT}) \mathrm{Cl}(\mathrm{MeCN})$ as the initiator (from which $\mathrm{MeCN}$ readily dissociates). ${ }^{2 \mathrm{f}}$ The reaction between $\mathbf{1 b}$ and five equivalents of $Z$-HFB in $\mathrm{C}_{6} \mathrm{D}_{6}$ at $22{ }^{\circ} \mathrm{C}$ generates $Z-(t-\mathrm{Bu}) \mathrm{CH}=\mathrm{CH}\left(\mathrm{CF}_{3}\right)$ and what we propose is $\mathrm{Mo}(\mathrm{N}-t-\mathrm{Bu})$ $\left(\mathrm{CHCF}_{3}\right)(\mathrm{OHIPT}) \mathrm{Cl}\left(\mathrm{PPh}_{2} \mathrm{Me}\right)(\mathbf{4 b})$. The reaction at $22{ }^{\circ} \mathrm{C}$ requires approximately $36 \mathrm{~h}$ to proceed to completion (at a concentration of $0.057 \mathrm{M}$ for $\mathbf{1 b}$ ). The alkylidene proton resonance in $4 \mathbf{b}$ in $\mathrm{C}_{6} \mathrm{D}_{6}$ is found at $9.66 \mathrm{ppm}$ as a broad and relatively featureless multiplet that spans $200 \mathrm{~Hz}(0.4 \mathrm{ppm})$ as a consequence of coupling of the alkylidene proton to both $\mathrm{P}$ and F. A broadband decoupled ${ }^{1} \mathrm{H}\left\{{ }^{31} \mathrm{P}\right\}$ NMR spectrum reveals the expected quartet multiplicity for the alkylidene proton with a ${ }^{3} \mathrm{~J}_{\mathrm{HF}}$ coupling constant of approximately 12.6 $\mathrm{Hz}$. The ${ }^{19} \mathrm{~F}$ NMR spectrum in $\mathrm{C}_{6} \mathrm{D}_{6}$ shows a doublet centered at $-54.3 \mathrm{ppm}\left({ }^{3} J_{\mathrm{HF}}=10.1\right.$ 
$\mathrm{Hz}$ ) for $Z-(t-\mathrm{Bu}) \mathrm{CH}=\mathrm{CH}\left(\mathrm{CF}_{3}\right)$ and a broad multiplet at -55.2 ppm for the $\mathrm{CF}_{3}$ group in $\mathbf{4 b}$. Addition of Bipy to the $\mathrm{C}_{6} \mathrm{D}_{6}$ solution of $\mathrm{Mo}(\mathrm{N}-t-\mathrm{Bu})\left(\mathrm{CHCF}_{3}\right)(\mathrm{OHIPT}) \mathrm{Cl}\left(\mathrm{PPh}_{2} \mathrm{Me}\right)$ gave $\mathrm{Mo}(\mathrm{N}-t-\mathrm{Bu})\left(\mathrm{CHCF}_{3}\right)(\mathrm{OHIPT}) \mathrm{Cl}(\mathrm{Bipy})(\mathbf{5 b})$ readily, as evidenced by the appearance of a quartet resonance at $11.29 \mathrm{ppm}\left({ }^{3} J_{\mathrm{HF}}=16.1 \mathrm{~Hz}\right)$ in $\mathrm{C}_{6} \mathrm{D}_{6}$ for the alkylidene proton. The corresponding ${ }^{19} \mathrm{~F}$ resonance for the $\mathrm{CF}_{3}$ group in $\mathbf{5 b}$ is found as a doublet at $-53.6 \mathrm{ppm}$ in $\mathrm{C}_{6} \mathrm{D}_{6}\left({ }^{3} J_{\mathrm{HF}}=16.2 \mathrm{~Hz}\right)$. An analogous reaction between $\mathrm{Mo}(\mathrm{N}-t-\mathrm{Bu})(\mathrm{CH}-t-\mathrm{Bu})$ (OHMT)Cl( $\left(\mathrm{PPh}_{2} \mathrm{Me}\right)$ and $Z$-HFB is too slow to yield an analogous $\mathrm{Mo}(\mathrm{N}-t-\mathrm{Bu})\left(\mathrm{CHCF}_{3}\right)$ $(\mathrm{OHMT}) \mathrm{Cl}\left(\mathrm{PPh}_{2} \mathrm{Me}\right)$ complex and first metathesis product, $Z-(t-\mathrm{Bu}) \mathrm{CH}=\mathrm{CH}\left(\mathrm{CF}_{3}\right)$, in any significant yield.

An X-ray structural study of $\mathbf{5 b}$ (Figure 3) showed it to be analogous to the other structures described here. The alkylidene proton was located in the difference Fourier map and refined semi-freely $\left(\mathrm{Mo} 1-\mathrm{C} 1-\mathrm{Hl}=118.1(15)^{\circ}\right)$. The Mo1-C1-C2 angle $\left(133.77(17)^{\circ}\right)$ is relatively normal for high oxidation state Mo syn alkylidene complexes, as is the $\mathrm{Mo}=\mathrm{C} 1$ distance (1.948(2) ̊; see SI).

Metathesis of cyano-substituted olefins (acrylonitrile) with molybdenum catalysts was first explored by Crowe, ${ }^{13}$ who used $\mathrm{Mo}\left(\mathrm{N}-2,6-i-\mathrm{Pr}_{2} \mathrm{C}_{6} \mathrm{H}_{3}\right)\left(\mathrm{CHCMe}_{2} \mathrm{Ph}\right)\left[\mathrm{OC}\left(\mathrm{CF}_{3}\right)_{2} \mathrm{Me}\right]_{2}$ as the initiator. Others have periodically explored similar metathesis reactions, mostly with ruthenium complexes. ${ }^{14}$ These reports, and the successful reactions between $\mathbf{1 b}$ and $Z$ $\mathrm{ClCH}=\mathrm{CHCl}$ or $Z-\left(\mathrm{CF}_{3}\right) \mathrm{CH}=\mathrm{CH}\left(\mathrm{CF}_{3}\right)$ just described, encouraged us to try to the reaction between $\mathbf{1 b}$ and $Z-(\mathrm{CN}) \mathrm{CH}=\mathrm{CH}(\mathrm{CN})$. Compound $\mathbf{1 b}$ reacts with two equivalents of $Z$ $(\mathrm{CN}) \mathrm{CH}=\mathrm{CH}(\mathrm{CN})$ in $\mathrm{C}_{6} \mathrm{D}_{6}$ at a concentration of $0.041 \mathrm{M}$ (for $\mathbf{1 b}$ ) at $22{ }^{\circ} \mathrm{C}$ to give $\mathrm{Mo}(\mathrm{N}-t-$ $\mathrm{Bu})(\mathrm{CHCN})(\mathrm{OHIPT}) \mathrm{Cl}\left(\mathrm{PPh}_{2} \mathrm{Me}\right)(\mathbf{6} \mathbf{b})$. The doublet alkylidene proton resonance for $\mathbf{6} \mathbf{b}$ in $\mathrm{C}_{6} \mathrm{D}_{6}$ is centered at $8.73 \mathrm{ppm}\left({ }^{3} J_{\mathrm{HP}}=7.4 \mathrm{~Hz} ; J_{\mathrm{CH}}=154 \mathrm{~Hz}\right)$. In a one bond ${ }^{1} \mathrm{H}_{-}{ }^{13} \mathrm{C}$ correlation (HSQC) NMR experiment the $\mathrm{C}_{\mathrm{a}}$ resonance was found to be at $231.1 \mathrm{ppm}$. Addition of Bipy to the solution of $\mathbf{6} \mathbf{b}$ gave $\mathrm{Mo}(\mathrm{N}-t-\mathrm{Bu})(\mathrm{CHCN})(\mathrm{OHIPT}) \mathrm{Cl}(\mathrm{Bipy})(\mathbf{7 b})$ in a slow reaction that required several hours. In situ NMR monitoring shows the formation of two singlets at $10.73 \mathrm{ppm}(25 \%)$ and $10.33 \mathrm{ppm}$ (75\%) for $\mathbf{7 b}$, which we ascribe to two isomers. The major alkylidene of $\mathbf{7 b}$ with the resonance at $10.33 \mathrm{ppm}$ in $\mathrm{C}_{6} \mathrm{D}_{6}$ is obtained selectively upon recrystallization of the mixture.

Crystals of $\mathbf{7 b}$ suitable for an X-ray study were grown upon addition of one equivalent of Bipy in a benzene solution of $\mathbf{6 b}$ which was left to stand without stirring. The $\mathrm{X}$-ray structural study (Figure 4 ) showed that $\mathbf{7 b}$ is analogous to $\mathbf{3 b}$ and $\mathbf{5 b}$, with the Bipy ligand coordinated trans to the alkylidene and the chloride ligands. The $t$-butyl imido and the HIPTO ligands occupy the apical positions. The alkylidene proton was located in the difference Fourier map and refined semi-freely $\left(\mathrm{Mo} 1-\mathrm{C} 1-\mathrm{Hl}=115.7(16)^{\circ}\right)$. The Mo1-C1-C2 angle $\left(129.21(18)^{\circ}\right)$ is relatively normal for high oxidation state Mo syn alkylidene complexes, as is the $\mathrm{Mo}=\mathrm{C} 1$ distance $(1.961(2) \AA)$; all are similar to analogous distances and angles found in $\mathbf{3 b}$ and $\mathbf{5 b}$ (see $\mathrm{SI}$ ).

Cross-metathesis reactions between $Z$-5-decene and either $Z$-DCE or $Z$-HFB catalyzed by monomeric complexes analogous to either $\mathbf{1 a}$ or $\mathbf{1} \mathbf{b}$ have been published; ${ }^{2}$ these reactions require formation of $\mathrm{Mo}=\mathrm{CHX}$ (where $\mathrm{X}=\mathrm{Cl}, \mathrm{CF}_{3}$ ) intermediates and reaction of them with the cross partner. We have confirmed that $\mathbf{2 b}$ and $\mathbf{4 b}$ are viable intermediates in reactions 
between $Z$-5-decene and a slight excess of $\mathrm{XCH}=\mathrm{CHX}\left(\mathrm{X}=\mathrm{Cl}\right.$ or $\mathrm{CF}_{3}$; eq 3$)$ and that the selectivity for formation of the $Z$ metathesis products approaches $100 \%$. The results are shown in Table 1.

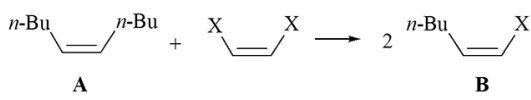

The cross-metathesis reaction between $Z$-5-decene and $Z$-DCE catalyzed by $\mathbf{2 b}$ proceeds efficiently at $22{ }^{\circ} \mathrm{C}$ to generate $Z$-1-chlorohexene, but $>1$ equiv of $Z$-DCE (relative to $Z$-5decene) is required for a high conversion to $\mathbf{B}$. The concentration of $\mathbf{2 b}$ (monitored by integrating the alkylidene resonance at $9.56 \mathrm{ppm}$ ) remains approximately constant throughout the course of the reaction. The rate of reaction begins to slow as $Z$-DCE is consumed and accelerates upon addition of more $Z$-DCE. The cross-metathesis experiment between $Z$-5-decene and $Z$-HFB initiated by $\mathbf{4 b}$ proceeds relatively efficiently only at $50{ }^{\circ} \mathrm{C}$. Although $\mathrm{PPh}_{2} \mathrm{Me}$ in $\mathbf{4 b}$ is rapidly exchanging (as evidenced by the broad alkylidene resonance at $9.66 \mathrm{ppm}$ ), the reaction between $\mathbf{4 b}$ and $Z-5$-decene is relatively slow.

Thus far, attempts to promote the cross-metathesis reaction shown in equation 1 through addition of one equiv of $\mathrm{B}\left(\mathrm{C}_{6} \mathrm{~F}_{5}\right)_{3}$ to $\mathbf{2} \mathbf{b}$ followed by the addition of the olefinic partners have failed. Addition of one equiv of $\mathrm{B}\left(\mathrm{C}_{6} \mathrm{~F}_{5}\right)_{3}$ to $\mathbf{2 b}$ in the absence of olefin leads to apparent catalyst decomposition (according to proton NMR spectra).

To our knowledge the Bipy derivatives of the $\mathrm{Mo}=\mathrm{CHCl}, \mathrm{Mo}=\mathrm{CHCF}_{3}, \mathrm{Mo}=\mathrm{CHCN}$, and $\mathrm{Mo}=\mathrm{CHPPh}_{2} \mathrm{Me}$ complexes reported here are the only structurally-characterized examples for molybdenum. Phosphoniomethylidene complexes are relatively well-known, especially for ruthenium, as noted earlier. Two $\mathrm{Ru}=\mathrm{CHF}$ complexes have been isolated and structurally characterized, ${ }^{3 a, e}$ but they are relatively unreactive toward unstrained olefins. An attempt to prepare a high oxidation state $\mathrm{W}=\mathrm{CHCN}$ complex led to a catalytically inactive tetramer, $\left\{\mathrm{W}(\mathrm{NAr})(\mathrm{CHCN})\left[\mathrm{OC}\left(\mathrm{CF}_{3}\right)_{2} \mathrm{Me}\right]_{2}\right\}_{4}$ and a tetrameric complex in which acetonitrile has inserted twice into the $\mathrm{W}=\mathrm{C}$ bond to give a diazatungstanacyclohexadiene complex. ${ }^{15}$ Addition of $\mathrm{CH}_{2}=\mathrm{CHX}$ (e.g., $\mathrm{X}=\mathrm{B}$ (pin), $\mathrm{PPh}_{2}, \mathrm{O}-n$-Pr, and $\mathrm{SPh}$, inter alia) to $\mathrm{Mo}(\mathrm{NAr})$ $(\mathrm{CHR})\left(\mathrm{Me}_{2} \mathrm{Pyr}\right)(\mathrm{OTPP})\left(\mathrm{Ar}=2,6-i-\mathrm{Pr}_{2} \mathrm{C}_{6} \mathrm{H}_{3}, \mathrm{R}=\mathrm{H}\right.$ or $\mathrm{CHCMe}_{2} \mathrm{Ph}, \mathrm{Me}_{2} \mathrm{Pyr}=2,5-$ dimethylpyrrolide, OTPP $\left.=\mathrm{O}-2,3,5,6-\mathrm{Ph}_{4} \mathrm{C}_{6} \mathrm{H}\right)$ complexes led to $\mathrm{Mo}(\mathrm{NAr})(\mathrm{CHX})\left(\mathrm{Me}_{2} \mathrm{Pyr}\right)$ (OTPP) complexes, ${ }^{16}$ but attempts to prepare $\mathrm{Mo}=\mathrm{CHCl}$ complexes in this manner failed. We could find no examples in the literature of structurally characterized $\mathrm{M}=\mathrm{CHCF}_{3}$ or $\mathrm{M}=\mathrm{CHCl}$ complexes.

We look forward to exploring the synthesis and reactions of the complexes reported here in more detail as well as preparing and exploring those that contain other electron-withdrawing groups in the alkylidene.

\section{ACKNOWLEDGMENT}

We are grateful for financial support from the National Institutes of Health (GM-59426) and from the National Science Foundation (CHE-1463707). 


\section{REFERENCES}

(1). (a)“A One-Pot Synthesis of m-Terphenyls via a Two-Aryne Sequence" Du CJF; Hart H; Ng KKD J. Org. Chem 1986, 51, 3162-3165.(b)"Isolation and X-ray crystal structure of a monomeric, $\sigma$ bonded aryllithium etherate complex [ $\left.\mathrm{Li}\left(\mathrm{Et}_{2} \mathrm{O}\right)_{2}-2,4,6-\mathrm{Ph}_{3} \mathrm{C}_{6} \mathrm{H}_{2}\right]$ " Power PP; Olmstead MM J. Organometal. Chem 1991, 408, 1-6.(c)"New terphenylphenoxides of group 13 and 14 elements" Stanciu C; Richards AF; Stender M; Olmstead MM; Power PP Polyhedron 2006, 25, 477-483.

(2). (a) "Direct Synthesis of Z-Alkenyl Halides by Catalytic Cross-Metathesis" Koh M-J; Nguyen TT; Zhang H; Schrock RR; Hoveyda AH Nature 2016, 531, 459-465. [PubMed: 27008965] (b) "Kinetically E-selective Catalytic Olefin Metathesis" Nguyen TT; Koh M-J; Shen X; Romiti F; Schrock RR; Hoveyda AH Science 2016, 352, 569-575. [PubMed: 27126041] (c)“Synthesis and Evaluation of Molybdenum and Tungsten Monoaryloxide Halide Alkylidene Complexes for ZSelective Cross Metathesis of Cyclooctene and Z-1,2-Dichloroethylene" Lam JK; Zhu C; Bukhryakov KV; Schrock RR; Müller PM; Hoveyda AH J. Am. Chem. Soc 2016, 138, 15774 15783. [PubMed: 27934034] (d)“Molybdenum Chloride Complexes as Catalysts for Stereoselective Olefin Metathesis" Koh MJ; Nguyen TT; Lam J; Torker S; Hyvl J; Schrock RR; Hoveyda AH Nature 2017, 542, 80-85. [PubMed: 28114300] (e)“'Synthesis of E- and Ztrisubstituted alkenes by catalytic cross-metathesis" Nguyen TT; Koh MJ; Mann TY; Schrock RR; Hoveyda AH Nature 2017, 552, 347-354. [PubMed: 29293209]

(3). (a)"Cross-Metathesis of Vinyl Halides. Scope and Limitations of Ruthenium-Based Catalysts" Macnaughtan ML; Gary JB; Gerlach DL; Johnson MJA; Kampf JW Organometallics 2009, 28, 2880-2887.(b)“Olefin Metathesis Reactions with Vinyl Halides: Formation, Observation, Interception, and Fate of the Ruthenium-Monohalomethylidene Moiety" Macnaughtan ML; Johnson MJA; Kampf JW J. Am. Chem. Soc 2007, 129, 7708-7709. [PubMed: 17542588] (c) "Olefin cross-metathesis with vinyl halides" Sashuk V; Samojlowicz C; Szadkowska A; Grela K Chem. Commun 2008, 2468-2470.(d)“Synthesis of Functionalized Olefins by Cross and RingClosing Metatheses" Chatterjee AK; Morgan JP; Scholl M; Grubbs RH J. Am. Chem. Soc 2000, 122, 3783-3784.(e)"Synthesis, Structure, and Olefin Metathesis Activity of Two Ruthenium Monofluoromethylidene Complexes" Macnaughtan ML; Johnson MJA; Kampf JW Organometallics 2007, 26, 780-782.(f)“Olefin Metathesis with 1,1-Difluoroethylene” Trnka TM; Day MW; Grubbs RH Angew. Chem., Int. Ed 2001, 40, 3441-3443.(g)“Improved reactivity in the conversion of nitrile-functionalized olefins by metathesis" Vancompernolle T; Vignona P; Trivelli X; Mortreux A; Gauvin RM Cat. Comm 2016, 77, 75-78.

(4). (a)"The Metathesis-Facilitated Synthesis of Terminal Ruthenium Carbide Complexes: A Unique Carbon Atom Transfer Reaction" Carlson RG; Gile MA; Heppert JA; Mason MH; Powell DR; Van der Velde D; Vilain JM J. Am. Chem. Soc 2002, 124, 1580-1581. [PubMed: 11853424] (b) "Two Generalizable Routes to Terminal Carbido Complexes" Caskey SR; Stewart MH; Kivela JE; Sootsman JR; Johnson MJA; Kampf JW J. Am. Chem. Soc 2005, 127, 16750-16751. [PubMed: 16316197]

(5). "Syntheses of Molybdenum Adamantylimido and $t$-Butylimido Alkylidene Chloride Complexes Using $\mathrm{HCl}$ and Diphenylmethylphosphine" Bukhryakov KV; VenkatRamani S; Tsay C; Hoveyda AH; Schrock RR Organometallics 2017, 36, 4208-4214.

(6). "Synthesis of 2,6-Hexatertiarybutylterphenyl Derivatives, 2,6-(2,4,6-t- $\left.\mathrm{Bu}_{3} \mathrm{C}_{6} \mathrm{H}_{2}\right){ }_{2} \mathrm{C}_{6} \mathrm{H}_{3} \mathrm{X}$, where $\mathrm{X}=\mathrm{I}, \mathrm{Li}, \mathrm{OH}, \mathrm{SH}, \mathrm{N}_{3}$, or $\mathrm{NH}_{2}$ ” Bukhryakov KV; Schrock RR; Hoveyda AH; Müller P; Becker J Org. Lett 2017, 19, 2607-2609. [PubMed: 28459588]

(7). (a)“High Oxidation State Multiple Metal-Carbon Bonds" Schrock RR Chem. Rev 2002, 102, 145180. [PubMed: 11782131] (b)"High Oxidation State Molybdenum and Tungsten Complexes Relevant to Olefin Metathesis” Schrock RR Handbook of Metathesis, Vol 1, 2nd Ed., WileyVCH, Weinheim, Grubbs RH and Wenzel AG, Ed., 2015, pp. 1-32.

(8). ${ }^{1} \mathrm{H}$ NMR $\left(\mathrm{C}_{6} \mathrm{D}_{6} ; 500 \mathrm{MHz} ; 22 \mathrm{C}\right)$ : Z-DCE : $5.52 \mathrm{ppm}\left({ }^{1} J_{\mathrm{CH}}=198.2 \mathrm{~Hz}\right)$; Z-HFB: $4.95 \mathrm{ppm}$ $\left({ }^{1} J_{\mathrm{CH}}=172.0 \mathrm{~Hz}\right)$; Z-Maleonitrile: $4.12 \mathrm{~Hz}\left({ }^{1} J_{\mathrm{CH}}=182.8 \mathrm{~Hz}\right)$.

(9). "Synthesis, Structure, and Spectroscopic Properties of Copper(II) Compounds containing Nitrogen-Sulphur Donor Ligands; the Crystal and Molecular Structure of Aqua[1,7-bis(Nmethylbenzimidazol-2'-yl)-2,6-dithiaheptane]copper(ii) Perchlorate” Addison AW; Rao TN; Van Rijn J; Veschoor GC; Reedijk J J. Chem. Soc., Dalton Trans 1984, 1349-1356. 
(10). (a)“The Coordination Chemistry of Ylides" Kaska WC Coord. Chem. Rev 1983, 48, 1-58.(b) "Organoactinoid chemistry with phosphoylids" Gilge JW; Cramer RE; Bruck MA; Higa KT; Panchanetheswaran K Inorg. Chim. Acta 1985, 110, 139-143.

(11). (a)"Heavily $\pi$-Bond-Loaded Tungsten Phosphonio-Alkylidyne Complexes via a Domino Transylidation Cascade at (Organoimido)tungsten Tetrachlorides" Li X; Schopf M; Stephan J; Harms K; Sundermeyer J Organometallics 2002, 21, 2356-2358.(b)“Synthesis of the First Stable 2-Chromaoxetane and its Homologues via a-Phosphonio(methylidene) Complexes of Hexavalent Chromium, Molybdenum, and Tungsten" Sundermeyer J; Weber K; Pritzkow H Angew. Chem. Int. Ed. Engl 1993, 32, 731.(c)“(a-Triphenylphosphonio)methylidene lmido Complexes of Molybdenum, Tungsten and Rhenium: the First Complexes Exhibiting Metal-Ligand Multiplebonding with TwoCarbon as well as Two Nitrogen Centres" Sundermeyer J; Weber K; Nürnberg O J. Chem. Soc., Chem. Commun 1992, 1631-1633.(d)"Phosphorus Ylide as a Precursor for the Formation of New High-Valent Tantalum Phosphonio Methylidyne Complexes" Li X; Wang A; Wang L; Sun H; Harms K; Sundermeyer J Organometallics 2007, 26, 1411-1413.(e)“Highervalent derivatives of the d-metal acids: XII. a-Phosphonio(methylidene) complexes of niobium and tantalum containing the metallocene-like $\left[\left(\eta^{5}-\mathrm{C}_{5} \mathrm{R}_{5}\right) \mathrm{M}\left(\mathrm{N}^{\mathrm{t}} \mathrm{Bu}\right)\right]$ core" Schmidt $\mathrm{S}$; Sundermeyer J; Möller F J. Organometal. Chem 1994, 475, 157-166.

(12). (a)"Rapidly Initiating Ruthenium Olefin-Metathesis Catalysts" Romero PE; Piers WE; McDonald R Angew. Chem., Int. Ed 2004, 43, 6161-6165.(b)“"Generation and Spectroscopic Characterization of Ruthenacyclobutane and Ruthenium Olefin Carbene Intermediates Relevant to Ring Closing Metathesis Catalysis" van der Eide EF; Romero PE; Piers WE; McDonald R J. Am. Chem. Soc 2008, 130, 4485-4491. [PubMed: 18321104] (c)“Thermal Decomposition Modes for Four-Coordinate Ruthenium Phosphonium Alkylidene Olefin Metathesis Catalysts" Leitao EM; Dubberley SR; Piers WE; Wu Q; McDonald R Chemistry 2008, 14, 11565-11572. [PubMed: 19035588] (d)“Mechanistic Studies on 14-Electron Ruthenacyclobutanes: Degenerate Exchange with Free Ethylene” Romero PE; Piers WE J. Am. Chem. Soc 2007, 129, 1698-1704. [PubMed: 17243686] (e)"Synthesis, characterization and olefin metathesis studies of a family of ruthenium phosphonium alkylidene complexes" Dubberley SR; Romero PE; Piers WE; McDonald R; Parvez M Inorg. Chim. Acta 2006, 359, 2658-2664.(f)“Direct Observation of a 14Electron Ruthenacyclobutane Relevant to Olefin Metathesis" Romero PE; Piers WE J. Am. Chem. Soc 2005, 127, 5032-5033. [PubMed: 15810833] (g)“Kinetic and Thermodynamic Analysis of Processes Relevant to Initiation of Olefin Metathesis by Ruthenium Phosphonium Alkylidene Catalysts" Leitao EM; van der Eide EF; Romero PE; Piers WE; McDonald R J. Am. Chem. Soc 2010, 132, 2784-2794. [PubMed: 20136131] (h)“A thermally robust ruthenium phosphonium alkylidene catalyst - the effect of more bulky N-heterocyclic carbene ligands on catalyst performance in olefin metathesis reactions" Leitao EM; Piers WE; Parvez M Can. J. Chem 2013, 91, 935-942.(i)"Photogeneration of a Phosphonium Alkylidene Olefin Metathesis Catalyst” Khalimon AY; Leitao EM; Piers WE Organometallics 2012, 31, 5634-5637.(j) "Ruthenium Metallacycles Derived from 14-Electron Complexes. New Insights into Olefin Metathesis Intermediates" Wenzel AG; Grubbs RH J. Am. Chem. Soc 2006, 128, 16048-16049. [PubMed: 17165753] (k)"Synthesis, structure and catalytic study of chloro-bridged two-core ruthenium carbene complexes" Qiao W; Shao M; Wang J J. Organometal. Chem 2012, 713, 197 202.

(13). "Acrylonitrile Cross-Metathesis: Coaxing Olefin Metathesis Reactivity from a Reluctant Substrate" Crowe WE; Goldberg DR J. Am. Chem. Soc 1995, 117, 5162-5163.

(14). (a)"A Practical and Highly Active Ruthenium-Based Catalyst that Effects the Cross-Metathesis of Acrylonitrile" Love JA; Morgan JP; Trnka TM; Grubbs RH Angew. Chem. Int. Ed 2002, 41, 4035-4037.(b) "Cross metathesis of bio-sourced fatty nitriles with acrylonitrile" Bidange J; Fischmeister C; Bruneau C; Dubois J-L; Couturier J-L Monats. Chemie 2015, 146, 1107-1113. (c)“A green route to nitrogen-containing groups: the acrylonitrile cross-metathesis and applications to plant oil derivatives" Miao X; Dixneuf PH; Fischmeister C; Bruneau C Green Chem 2011, 13, 2258-2271.(d)"Highly active phosphine-free carbene ruthenium catalyst for cross-metathesis of acrylonitrile with functionalized olefins" Bai C-X; Zhang W-Z; He R; Lu XB; Zhang Z-Q Tetrahedron Letters 2005, 46, 7225-7228.(e)“Highly selective cross metathesis with acrylonitrile using a phosphine free Ru-complex" Randl S; Bessler S; Wakamatsu H; Blechert S Synlett 2001, 3, 430-432.(f)"Nitro-Substituted Hoveyda-Grubbs Ruthenium Carbenes: Enhancement of Catalyst Activity through Electronic Activation” Michrowska AB; 
Bujok R; Harutyunyan S; Sashuk V; Dolgonos G; Grela K J. Am. Chem. Soc 2004, 126, 9318 9325. [PubMed: 15281822] (g)"Tandem Catalytic Acrylonitrile Cross-Metathesis and Hydrogenation of Nitriles with Ruthenium Catalysts: Direct Access to Linear a, $\omega$-Aminoesters from Renewables" Miao X; Fischmeister C; Bruneau C; Dixneuf PH; Dubois J-L; Couturier J-L Chem Sus Chem 2012, 5, 1410-1414.(h)"Renewable materials as precursors of linear nitrile-acid derivatives via cross-metathesis of fatty esters and acids with acrylonitrile and fumaronitrile" Malacea R; Fischmeister C; Bruneau C; Dubois J-L; Couturier J-L; Dixneuf PH Green Chem 2009, 11, 152-155.(i)“Improved reactivity in the conversion of nitrile-functionalized olefins by metathesis" Vancompernolle T; Vignon P; Trivelli X; Mortreux A; Gauvin RM Catal Comm 2016, 77, 75-78.(j) “Effective and Inexpensive Acrylonitrile Cross-Metathesis: Utilisation of Grubbs II Precatalyst in the Presence of Copper(I) Chloride" Rivard M; Blechert S Eur. J. Org. Chem 2003, 2225-2228.(k)“Alkene metathesis: the search for better catalysts” Deshmukh PH; Blechert S Dalton Trans 2007, 2479-2491. [PubMed: 17563782] (1)“Ruthenium-alkylidene catalysed cross-metathesis of fatty acid derivatives with acrylonitrile and methyl acrylate: a key step toward long-chain bifunctional and amino acid compounds" Miao X; Malacea R; Fischmeister C; Bruneau C Dixneuf PH Green Chem 2011, 13, 2911-2919.(m)“AA Highly Efficient Ruthenium Catalyst for Metathesis Reactions" Grela K; Harutyunyan S; Michrowska AB Angew. Chem 2002, 114, 4210-4212.

(15). "Structure and reactivity studies of the first tungsten cyanoalkylidene complex" Cameron TM; Gamble AS; Abboud KA; Boncella JM Chem. Commun 2002, 1148-1149.

(16). "Synthesis of High Oxidation State Molybdenum Imido Heteroatom-Substituted Alkylidene Complexes" Townsend EM; Kilyanek SM; Schrock RR; Müller P; Smith SJ; Hoveyda AH Organometallics 2013, 32, 4612-4617. [PubMed: 24082360] 


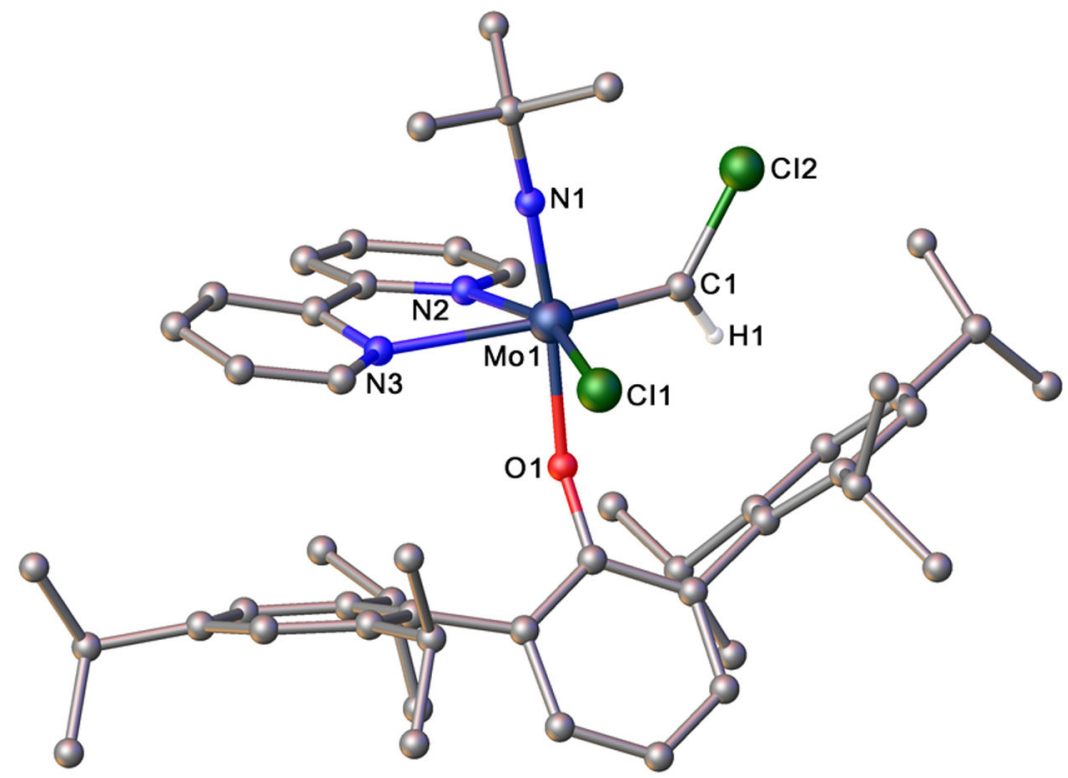

Figure 1.

Molecular structure of $\mathrm{Mo}(\mathrm{N}-t-\mathrm{Bu})(\mathrm{CHCl})(\mathrm{OHIPT}) \mathrm{Cl}(\mathrm{Bipy})$. All hydrogen atoms (except on $\mathrm{C} 1)$, lattice solvent, and disordered atoms have been omitted for clarity. 


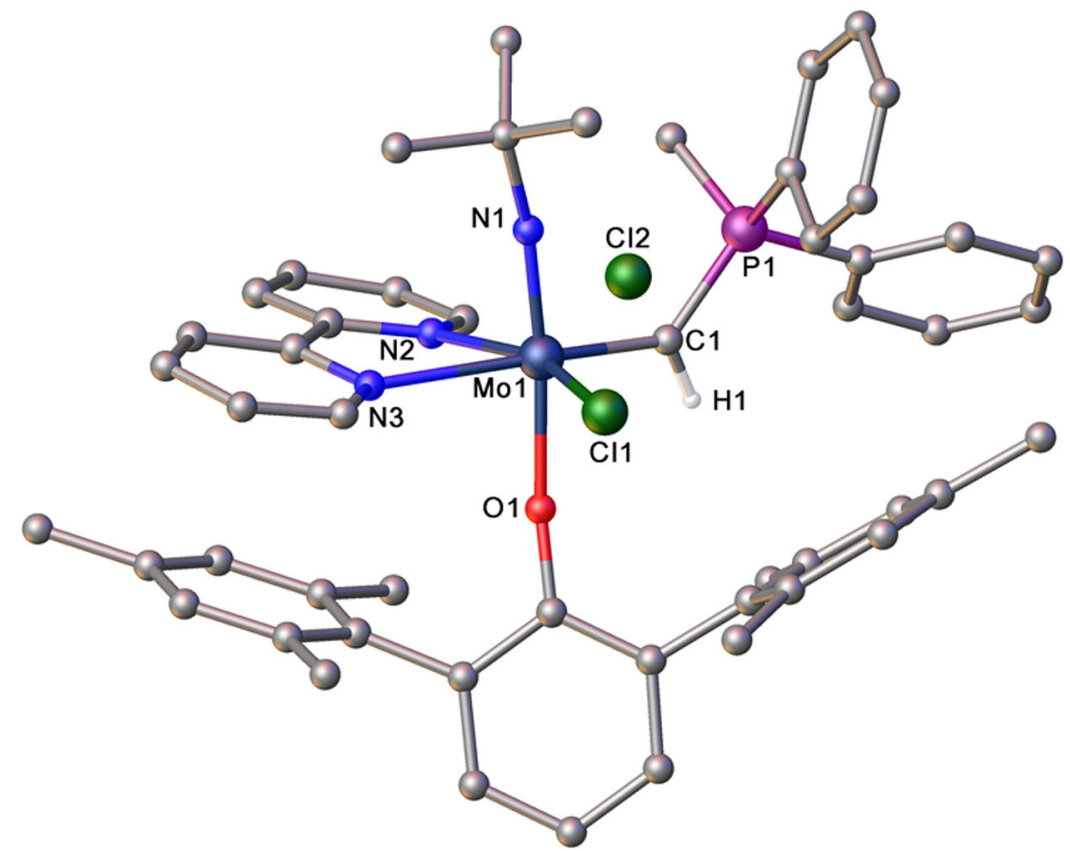

Figure 2.

Molecular structure of $\left[\mathrm{Mo}(\mathrm{N}-t-\mathrm{Bu})\left(\mathrm{CHPPh}_{2} \mathrm{Me}\right)(\mathrm{OHMT}) \mathrm{Cl}(\mathrm{Bipy})\right] \mathrm{Cl}$. All hydrogen atoms (except on $\mathrm{C} 1$ ) and lattice solvent have been omitted for clarity. 


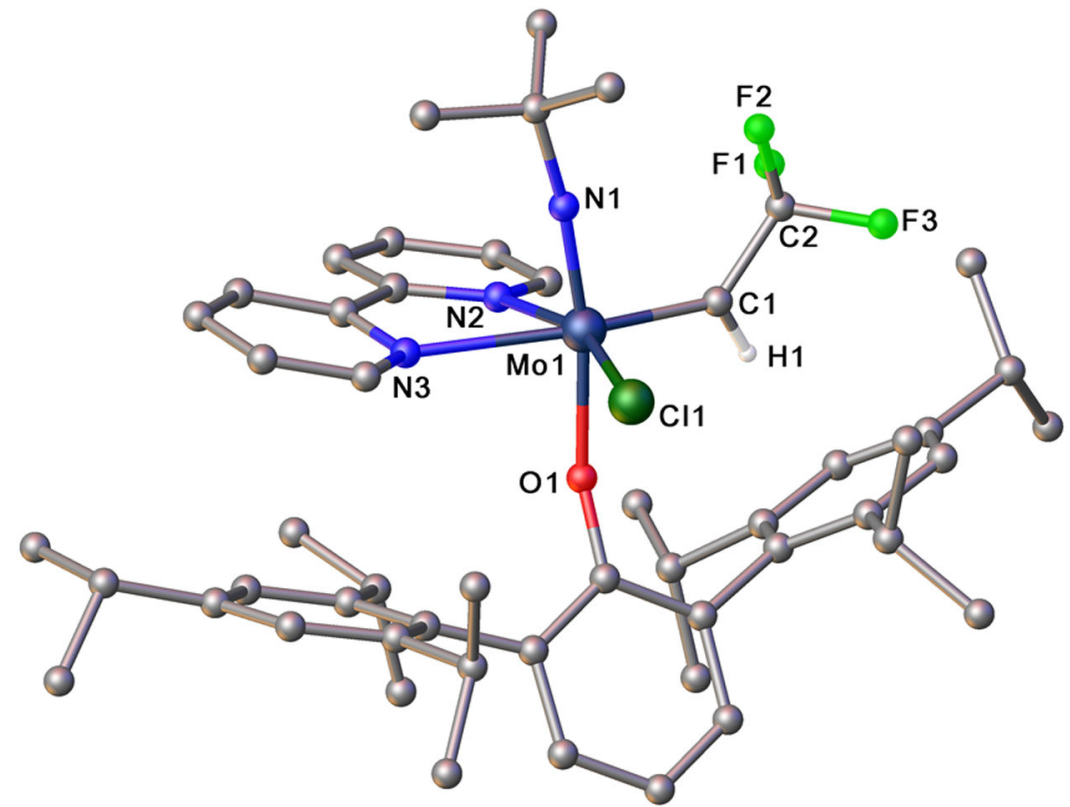

Figure 3.

Molecular structure of $\mathrm{Mo}(\mathrm{N}-t-\mathrm{Bu})\left(\mathrm{CHCF}_{3}\right)(\mathrm{OHIPT}) \mathrm{Cl}(\mathrm{Bipy})$. All hydrogen atoms (except on $\mathrm{C} 1$ ), lattice solvent, and disordered atoms have been omitted for clarity. 


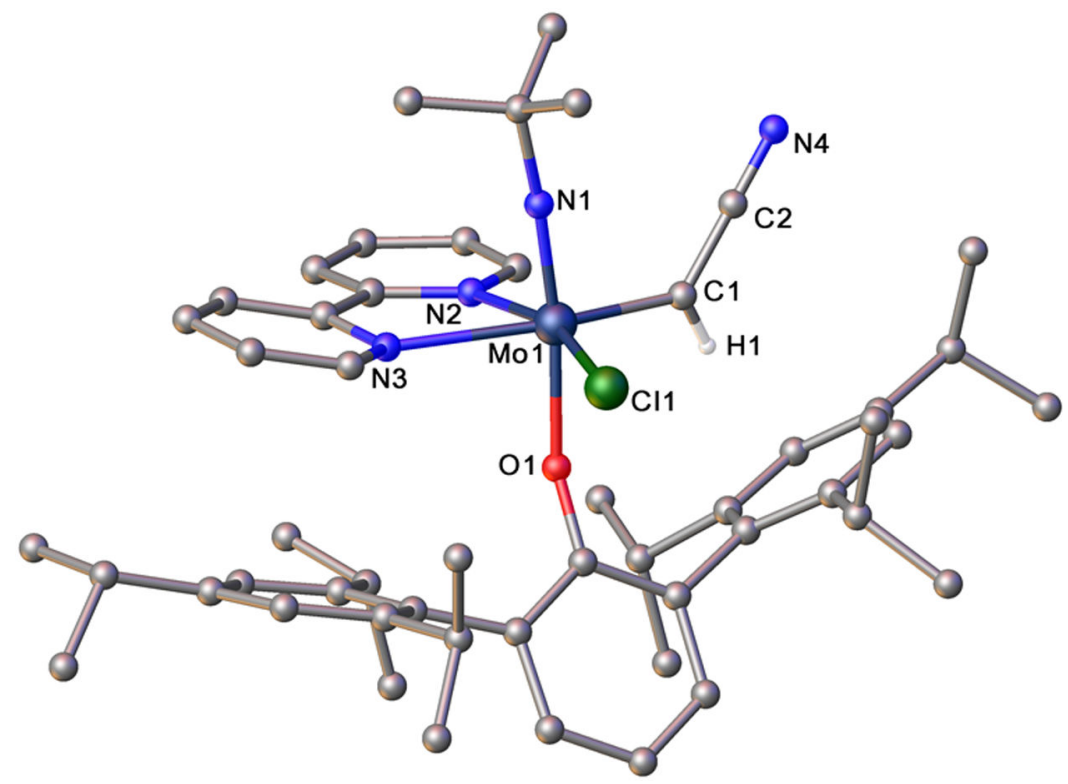

Figure 4.

Molecular structure of $\mathrm{Mo}(\mathrm{N}-t-\mathrm{Bu})(\mathrm{CH}(\mathrm{CN}))(\mathrm{OHIPT}) \mathrm{Cl}(\mathrm{Bipy})$. All hydrogen atoms (except on $\mathrm{C} 1$ ), lattice solvent, and disordered atoms have been omitted for clarity. 
Table 1.

Results of reactions between $\mathbf{2 b}$ and $\mathbf{4 b}$ with $Z-5$-Decene and $Z-\mathrm{XCH}=\mathrm{CHX}$ in $\mathrm{C}_{6} \mathrm{D}_{6}\left(\mathrm{X}=\mathrm{Cl}_{\text {or }} \mathrm{CF}_{3}\right)$.

\begin{tabular}{lllll}
\hline Equivof A & $\mathbf{X}$ & $\mathbf{T}\left({ }^{\circ} \mathbf{C}\right)$ & \% Conv to B (120 min) & \% Z $\mathbf{~ o f ~ B ~}$ \\
\hline $\mathbf{3}$ & $\mathrm{Cl}$ & 22 & $66^{a}$ & $>99^{b}$ \\
$\mathbf{1 0}^{\mathrm{c}}$ & $\mathrm{CF}_{3}$ & 50 & 82 & $>99^{c}$ \\
\hline${ }^{a}$ Addition of two equiv of $Z$-DCE generates $>99 \%$ of the expected $\mathbf{B}$. \\
${ }^{b}$ Determined by GC. \\
${ }^{c}$ Determined by ${ }^{19}$ F NMR spectroscopy.
\end{tabular}

